\title{
PEMILIHAN KEPUTUSAN PENGGUNAAN SODA API (NaOH) SEBAGAI ALTERNATIF PENGGANTI THINNER CAIRAN PEMBERSIH CAT PADA LOGAM DENGAN MENGGUNAKAN METODE
}

\section{Analityc Network Process (ANP)}

\author{
Bangkit Tri Pramesti ${ }^{1}$, Rini Oktavera ${ }^{2}$ dan Victor Yuardi Risonarta ${ }^{3}$ \\ $\left[{ }^{1,3}\right]$ Program Studi Teknik Industri, Universitas Katolik Darma Cendika \\ $\left.{ }^{2}\right]$ Program Studi Teknik Industri, Universitas WR. Supratman \\ bangkitpramesti008@gmail.com,rini.oktavera@gmail.com
}

\begin{abstract}
Many Indonesians still use Thinner as paint cleaner solution. Thinner is a compound of petroleum. Petroleum is a non-renewable natural resource. Under these conditions, alternatives are needed that can be used either to replace or reduce the use of thinner. The alternative to use chemicals is caustic soda (NaOH). The criterion and sub-criteria which is to know the priority of use in choosing cleaning fluid of paint chemical obtained by conducting interview with user of caustic and thinner liquid to clean paint. The result of the interview is processed into questionnaires and calculated using ANP obtained 5 criteria (Economics, Environment, Technical, Concentration and Time) and 10 sub- criteria. Decision-making alternative to thinner cleaning paint alternator using ANP method gives higher priority value of caustic soda that is 0.67617 or $67.6 \%$ compared with thinner priority value of 0.392383 or $39.3 \%$. So caustic soda is an alternative liquid to replace the thinner as a cleaning fluid. The optimal concentration of liquid caustic soda $(\mathrm{NaOH})$ is $187.5 \mathrm{M}$ with a mixture of 150 grams of water with a volume of water / aquades of 20 $\mathrm{ml}$ resulting in a 10-minute peel time.
\end{abstract}

Keywords: Caustic Soda, ANP, DOE, Decision Selection

\section{PENDAHULUAN}

Dewasa ini sering kita jumpai sebagian besar masyarakat Indonesia masih menggunakan thinner untuk menghilangkan ataupun mengelupas cat pada logam. Thinner merupakan larutan yang memiliki komposisi dari beberapa tipe solvent dan merupakan bahan campuran yang digunakan dalam proses pengecatan.

Thinner mengandung senyawa toluena yang diperoleh dari turunan senyawa benzena yang merupakan senyawa penyusun minyak bumi. Minyak bumi merupakan sumber daya alam yang tidak dapat diperbaharui. Namun minyak bumi masih banyak digunakan dalam kehidupan masyarakat, seperti bahan bakar kendaraan bermotor dan pesawat, minyak tanah, aspal dan thinner. Cadangan dan produksi bahan bakar minyak bumi (fosil) di Indonesia mengalami penurunan $10 \%$ setiap tahunnya sedangkan tingkat konsumsi minyak rata-rata naik 6\% per tahun. (Priyohadi dkk, 2013). Dengan kondisi seperti diatas akan diperlukan alternatif yang dapat digunakan baik untuk menggantikan maupun mengurangi penggunaan thinner yang merupakan salah satu aplikasi dari minyak bumi. Alternatif yang akan digunakan menggunakan bahan kimia adalah soda api $(\mathrm{NaOH})$.

Pengambilan keputusan meliputi mengidentifikasi masalah, pencarian alternatif penyelesaian masalah, evaluasi dari alternatif alternatif tersebut dan pemilihan alternatif keputusan yang terbaik. Keputusan untuk melakukan mencari alternatif cairan kimia pembersih cat selain thinner diperlukan informasi yang dapat menganalisa keputusan tersebut. Metode Design of Experiments (DoE) digunakan untuk menyediakan informasi dan analisa terhadap keputusan pemilihan cairan kimia pembersih cat dengan adanya pengaruh dari faktor- faktor yang dapat dikendalikan maupun yang tidak dapat dikendalikan.

Metode Analytic Network Process (ANP) digunakan dalam penyelesaian masalah yang di dalamnya ada keterkaitan antar kriteria (Jharkharia dan Shankar, 2005). Penentuan prioritas dalam ANP sama dengan penentuan prioritas dalam AHP yang menggunakan skala 
perbandingan dan pembobotan.

Penelitian ini bertujuan untuk menentukan cairan pembersih cat selain thinner menggunakan metode ANP.

Pemakaian sisten pendukung keputusan ANP sudah banyak diterapkan misalkan saja pada Jurnal Teknik Informatika Universitas Dian Nuswantoro Semarang yang dilakukan oleh (Arief Genta Aldiansyah) dengan judul "Sistem Pendukung Keputusan Pemilihan Telepon Seluler Menggunakan Analytic Network Process (ANP)". Terdapat 5 kriteria, 11 sub kriteria, dan 4 alternatif yang digunakan pada pemilihan ponsel untuk pemilihan jenis handphone. Nilai ratio konsistensi untuk perbandingan konsistensi index adalah 0,067\% dibawah ketentuan CR $\leq 10 \%$ sehingga perbandingan dianggap konsisten dengan ponsel selluler sebagai pilihan yang sesuai. Sehingga pemilihan handphone menggunakan metode ANP membantu konsumen dalam hal pemilihan handphone sesuai kegunaan dan spesifikasi menyesuaikan dana yang dimiliki oleh konsumen.

Pada Jurnal ITB (Desvia Safitri, Mochammad Chaerul, Emenda Sembiring) dengan judul "Multi Kriteria Terhadap Pemilihan Alternatif Pengelolaan Sampah Organik Dengan Menggunakan Metode Analytic Network Process (ANP)". Dalam studi ini diidentifikasi 18 sub kriteria dalam 4 kriteria (ekonomi, lingkungan, sosial, teknis, dan kelembagaan). Skenario Alternatif pengolahan sampah organik yang dianalisis terdiri atas kombinasi pengomposan, insinerasi, dan landfill. Hasil perhitungan menunjukkan kriteria sosial $(0,292)$ dan lingkungan $(0,249)$ merupakan pertimbangan utama dalam pemilihan alternatif pengolahan sampah organik. Sintesis prioritas skenario pengomposan di sumber skala kelurahan dan landfilling merupakan preferensi dengan bobot tertinggi $(0,320)$.

Perbedaan penelitian saat ini dengan penelitan terdahulu adalah penelitian ini menggunakan metode ANP pada obyek soda api dan thinner yang memiliki 5 kriteria digunakan untuk pengambilan keputusan dalam pemilihan alternatif yaitu ekonomi, lingkungan, konsentrasi, teknis, dan waktu. Data diperoleh dengan melakukan pembobotan untuk kriteria dan alternatif yang dibandingkan dengan menggunakan skala Saaty dan hasil yang diperoleh menggunakan bantuan ANP Software Super Decisions.

\section{TINJAUAN PUSTAKA}

\subsection{Analytic Network Process (ANP)}

Analytic Network Process (ANP) adalah teori matematis yang memungkinkan seorang pengambil keputusan menghadapi faktor-faktor yang saling berhubungan (dependence) serta umpan balik (feedback) secara sistematik. ANP merupakan satu dari metode pengambilan keputusan berdasarkan banyaknya kriteria atau Multi Criteria Decision Making (MCDM) yang dikembangkan oleh Thomas L Saaty. Metode ini merupakan pendekatan baru metode kualitatif yang merupakan perkembangan lanjutan dari metode terdahulu yakni Analytic Hierarchy Process (AHP) (Tanjung dan Devi, 2013). Metode Analytic Network Process (ANP) merupakan generalisasi dari AHP. ANP juga mampu memperbaiki kelemahan AHP berupa kemampuan mengakomodasi keterkaitan antar kriteria atau alternatif (Saaty, 2008). Metode Analytic Network Process (ANP) adalah salah satu metode yang mampu merepresentasikan tingkat kepentingan berbagai pihak dengan mempertimbangkan saling keterkaitan antar kriteria pada level struktur dan sub kriteria yang ada.

Kelebihan ANP dari metode yang lain adalah kemampuannya untuk membantu para pengambil keputusan dalam melakukan pengukuran dan sintesis sejumlah faktorfaktor dalam hirarki atau jaringan. Banyak kelebihan dari metode baru yang diperkenalkan oleh Saty ini, yang diantaranya adalah kesederhanaan konsep yang ditawarkan. Menurut Saaty (Tanjung dan Devi, 2013) dari kesederhanaan metodenya membuat ANP menjadi metode yang lebih umum dan lebih mudah diaplikasikan untuk studi 
kualitatif yang beragam, seperti pengambilan keputusan, peramalan (forecasting), evaluasi, pemetaan (maaping), strategizing, alokasi sumber daya dan lain sebagainya.

Pada umumnya penelitian dengan pendekatan kualitatif hanya mendeskripsikan hasil penemuan yang ada dilapangan tanpa melakukan sintetis lebih dalam. Terlebih lagi jika dibandingkan dengan metode AHP, ANP memiliki banyak kelebihan, seperti perbandingan yang dihasilkan lebih objektif, kemampuan prediktif yang lebih akurat, dan hasil yang lebih stabil.

\subsection{Design of Experimets (DoE)}

Pengertian DoE menurut Anthony, 2001 adalah Design and Analysis of Experimets (DoE) atau bias disebut juga desain eksperimen atau perancangan percobaan merupakan ilmu statistik yang banyak digunakan oleh industri - industri. Aplikasi DoE dapat dipakai dalam bidang manajemen, manufaktir, engineering, dan juga science. DoE adalah teknik ampuh yang melibatkan proses perencanaan dan desain suatu percobaan sehingga data yang tepat biasa dikumpulkan dan diolah secara statistik yang pada akhirnya mendapatkan kesimpulan yang valid.

Statistik Design of Eksperiments (DoE) didasari pada proses perencanaan percobaan, sehingga data yang sesuai akan didapatkan yang bisa dianalisa dengan objektif. Pengolahan data dengan menggunakan statistik diperlukan untuk menganalisis terjadinya kesalahan percobaan (experimental errors). Ketika masalah melibatkan data yang merupakan satu - satunya pendekatan objektif untuk menganalisis. Perancangan percobaan dan pengolahan secara statistik merupakan dua hal yang berhubungan dan harus dipelajari bersama - sama. Tiga prinsip dasar dalam melakukan perancangan percobaan adalah replicaton, blocking, dan randomization.

\section{METODE PENELITIAN}

Tahapan awal dalam penelitian ini adalah mengidentifikasikan permasalahan yang akan dijawab pada penelitian ini. Permasalahan yang terjadi adalah apakah cairan soda api $(\mathrm{NaOH})$ dapat dijadikan sebagai alternative cairan pembersih cat pada logam. Permasalahan yang ada akan ditinjau dari studi lapangan dan studi pustaka. Setelah studi pustaka dan studi lapangan dilakukan, kuesioner sebagai alat pengukuran pada penelitian ini dilakukan terhadap 10 responden yang pernah menggunakan cairan thinner maupun soda api $(\mathrm{NaOH})$ yang kemudian hasil kuesioner di olah menggunakan software super decisions. Dari hasil pengolahan akan didapatkan kriteria dan sub-kriteria yang merupakan prioritas bagi pengguna dalam memilih cairan pembersih cat serta didapatkan hasil nilai prioritas masing - masing cairan. Kemudian melakukan eksperimen menggunakan metode DoE untuk mengetahui konsentrasi optimal soda api untuk mengelupas cat, nilai prioritas cairan tinggi dan konsentrasi optimal yang didapatkan untuk dilakukan penarikan kesimpulan dan saran.

\section{HASIL DAN PEMBAHASAN}

\subsection{Model Jaringan Jaringan ANP}

Penentuan kriteria yang digunakan untuk pemilihan alternatif cairan pembersih cat didapatkan dalam wawancara yang dituangkan dalam bentuk kuesioner tertutup dan pada tahap ini didapati perlu ada kriteria ekonomi, lingkungan, teknis, konsentrasi, dan waktu yang perlu diperhatikan dalam melakukan pemilihan cairan pembersih cat. Adapun hasil diskusi dan kuesioner terbuka menghasilkan 5 kriteria dan 10 sub-kriteria

Perangkat lunak Super Decisions digunakan untuk pengambilan keputusan dalam ketergantungan dan umpan balik yang merupakan implementasi ANP Software Super Decisions.

Berdasarkan hasil pengecekkan semua matriks perbandingan memiliki rasio inkonsistensi kurang dari 0.1 hal ini berarti pengisian kuesioner memiliki hasil yang realiable 


\begin{tabular}{|l|l|l|}
\cline { 2 - 3 } \multicolumn{2}{c|}{ Inconsistency: 0.04087} \\
\hline Ekonomi & & 0.21143 \\
\hline Konsentra & & 0.05161 \\
\hline Lingkungan & & 0.49623 \\
\hline Teknis & & 0.15275 \\
\hline Waktu & & 0.08798 \\
\hline
\end{tabular}

Gambar 3 Nilai Konsistensi pada Software Super Decisions

\subsection{Membentuk Supermatriks}

Seperti yang sudah dijelaskan sebelumnya, penggunaan ANP kita akan mendapatkan tiga supermatriks yang dibentuk yaitu yang pertama adalah unweighted supermatrix yang didapat dari masukkan nilai suatu keterkaitan antar suatu kriteria

dengan yang lain, setelah itu kita masukkan bobot antar cluster untuk mendapat weight supermatrix lalu yang terakhir kita akan mendapatkan limit supermatrix akan didapat dari memangkatkan hasil dari weight supermatrix kemudian di konvergenkan. Selanjutnya penulis akan menguraikan penjelasan dari limit supermatrix.

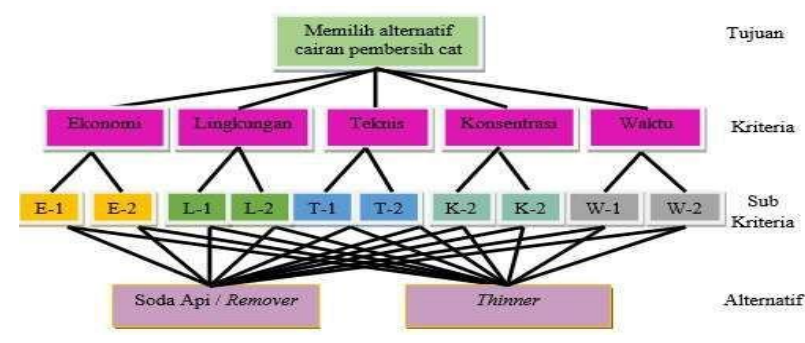

Gambar 1 Jaringan ANP

Pemodelan struktur jaringan dapat juga dilakukan dengan menggunakan bantuan perangkat lunak Super Decisions. Konstruksi model dapat dilihat pada gambar 2.

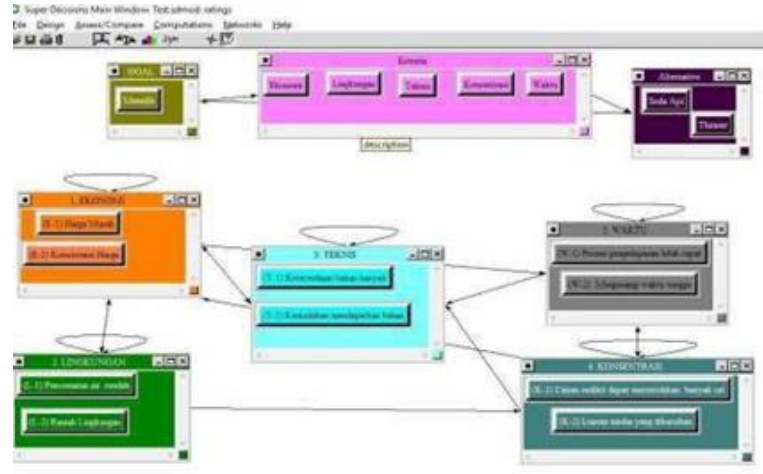

Gambar 2. Konstruksi Model ANP pada Software Super Decisions

\subsubsection{Analisis Unweighted Supermatrix}

Pada unweighted supermatrix terdapat dua hal yang dapat dilihat yaitu ada pengaruh atau tidaknya interaksi antar subkriteria dan jika ada seberapa besar pengaruh tersebut.

Ketika sub-kriteria hanya dipengaruhi oleh satu kriteria saja maka nilai pengaruh tersebut adalah 1. Hal ini dapat dilihat pada cluster ekonomi pada tabel dibawah ini, dimana pada sub-kriteria harga murah hanya dipengaruhi oleh sub-kriteria konsistensi harga dan sub-kriteria konsistensi harga juga hanya dipengaruhi oleh sub-kriteria harga murah saja. Sehingga nilai pengaruh harga murah pada konsistensi harga senilai 1.000000 .

Tabel 2 Unweighted Supermatrix Pada Cluster Ekonomi

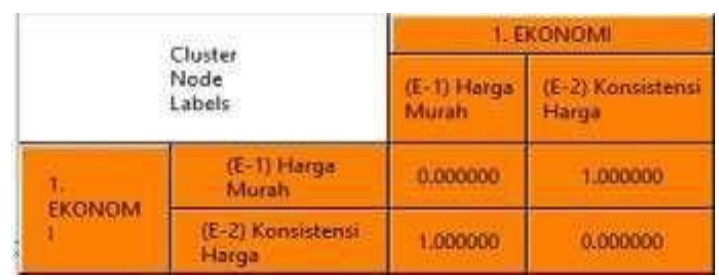

\subsubsection{Analisis Weighted Supermatrix}

Weighted Supermatrix merupakan hasil kali unweighted spermatrix terhadap bobot pengaruh kriteria. Perbandingan nilai pengaruh suatu sub- kriteria terhadap subkriteria lainnya pada weighted supermatrix nilai pengaruh tersebut dikali bobot yang sama pada tiap kriterianya. 


\subsubsection{Analisis Limit Supermatrix}

Pada bagian ini penulis akan menjelaskan hasil bobot kriteria yang penulis dapatkan setelah mengolah data dengan menggunakan Software Super Decisions.

Tabel 3 Urutan Bobot Kriteria

\begin{tabular}{|c|l|c|}
\hline No & Kriteria & Bobot \\
\hline 1 & Lingkungan & 0.496230 \\
\hline 2 & Ekonomi & 0.211425 \\
\hline 3 & Teknis & 0.152754 \\
\hline 4 & Waktu & 0.087980 \\
\hline 5 & Konsentrasi & 0.051611 \\
\hline
\end{tabular}

Dilihat dari bobot tersebut, dapat disimpulkan bahwa bobot untuk konsentrasi merupakan nilai yang paling kecil yaitu bernilai 0.051611 yang berarti kriteria konsentrasi memberikan kontribusi yang kecil pada pemilihan

alternatif cairan pembersih cat, sedangkan kriteria yang akan memberikan pengaruh paling besar adalah lingkungan, karena mempunyai bobot prioritas yang paling besar yaitu senilai 0.496230

Sama halnya dengan bobot kriteria, pada bobot sub-kriteria juga didominasi oleh kriteria yang mengandung unsur lingkungan. Berikut penulis menampilkan urutan bobot prioritas sub-kriteria yang didapat dari perhitungan dengan menggunakan Software Super Decisions.

Tabel 3 Urutan Bobot Sub-Kriteria

\begin{tabular}{|c|l|c|}
\hline No & \multicolumn{1}{|c|}{ Kriteria } & Bobot \\
\hline & Ramah Lingkungan & 0.68248 \\
\hline 2 & Ketersediaan Bahan Banyak & 0.67524 \\
\hline 3 & Proses pengelupasan lebih & 0.65878 \\
\hline 4 & Harga murah & 0.58016 \\
\hline 5 & Luasan media yang & 0.54998 \\
\hline 6 & Cairan sedikit dapat & 0.45002 \\
\hline 7 & Konsistensi harga & 0.41984 \\
\hline 8 & Mengurangi waktu tunggu & 0.34122 \\
\hline
\end{tabular}

\begin{tabular}{|c|l|c|}
\hline 9 & Kemudahan mendapatkan & 0.32476 \\
\hline 10 & Pencemaran air rendah & 0.31752 \\
\hline
\end{tabular}

Dari tabel tersebut diatas didapat bahwa bobot prioritas tertinggi merupakan sub-kriteria dari lingkungan, hal ini mempertegas dari analisa bobot kriteria bahwa kriteria yang mengandung unsur lingkungan memang dibutuhkan oleh pihak bengkel dalam melakukan pemilihan alternatif cairan pembersih cat.

\subsection{Pemberian Rating Alternatif Cairan}

Setelah mendapatkan bobot kriteria, maka kita akan meminta para expert untuk melakukan penilaian kepada kedua alternatif tersebut, berikut merupakan hasil bentuk rating prioritas menggunakan Software Super Decisions yang kami peroleh dari para expert tersebut:

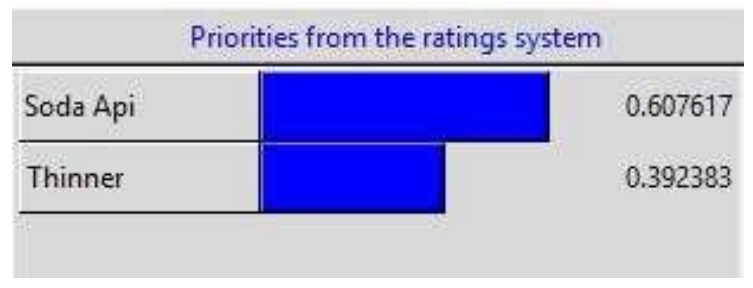

Gambar 4 Hasil Rating Alternatif

Dari gambar diatas dapat dijelaskan sebagai berikut: alternatif menggunakan cairan soda api memiliki nilai rating prioritasnya adalah 0.607617 atau $60.7 \%$ dan alternatif menggunakan cairan thinner diperoleh nilai prioritasnya adalah 0.392382 atau $39.2 \%$.

\subsection{Mencari Konsetrasi Optimal}

Penelitian ini melibatkan 2 faktor yang terdiri dari :

1. Faktor massa soda api (P)

Dengan taraf faktor: $50 \mathrm{gr}, 100 \mathrm{gr}$, dan $150 \mathrm{gr}$

2. Faktor volume air / aquades (L)

Dengan taraf taraf faktor: $20 \mathrm{ml}, 50 \mathrm{ml}$ dan $70 \mathrm{ml}$

Rancangan percobaan yang digunakan adalah RAL (Rancangan Acak Lengkap) 
faktorial dengan 2 faktor. Dengan demikian dalam penelitian ini masing - masing dilakukan 3 kali ulangan. Sehingga secara keseluruhan menghasilkan $3 \times 3 \times 3$ kombinasi dengan jumlah keseluruhan 27 unit percobaan.

Tabel 4 Tabulasi Data Konsentrasi Larutan

\begin{tabular}{|c|c|c|c|c|}
\hline $\begin{array}{c}\text { Soda Api } \\
\text { (massa) }\end{array}$ & Ulangan & \multicolumn{3}{|c|}{ Air / Aquades (Volume) } \\
\cline { 2 - 5 } & & $\mathbf{2 0} \mathbf{~ m l}$ & $\mathbf{5 0} \mathbf{~ m l}$ & $\mathbf{7 0} \mathbf{~ m l}$ \\
\hline \multirow{3}{*}{$\mathbf{5 0}$ gr } & 1 & $62.5 \mathrm{M}$ & $25 \mathrm{M}$ & $17.9 \mathrm{M}$ \\
\cline { 2 - 5 } & 2 & $62.5 \mathrm{M}$ & $25 \mathrm{M}$ & $17.9 \mathrm{M}$ \\
\cline { 2 - 5 } & 3 & $62.5 \mathrm{M}$ & $25 \mathrm{M}$ & $17.9 \mathrm{M}$ \\
\hline \multirow{3}{*}{$\mathbf{1 0 0}$ gr } & 1 & $125 \mathrm{M}$ & $50 \mathrm{M}$ & $35.8 \mathrm{M}$ \\
\cline { 2 - 5 } & 2 & $125 \mathrm{M}$ & $50 \mathrm{M}$ & $35.8 \mathrm{M}$ \\
\cline { 2 - 5 } & 3 & $125 \mathrm{M}$ & $50 \mathrm{M}$ & $35.8 \mathrm{M}$ \\
\hline \multirow{3}{*}{$\mathbf{1 5 0}$ gr } & 1 & $187.5 \mathrm{M}$ & $75 \mathrm{M}$ & $53.6 \mathrm{M}$ \\
\cline { 2 - 5 } & 2 & $187.5 \mathrm{M}$ & $75 \mathrm{M}$ & $53.6 \mathrm{M}$ \\
\cline { 2 - 5 } & 3 & $187.5 \mathrm{M}$ & $75 \mathrm{M}$ & $53.6 \mathrm{M}$ \\
\hline
\end{tabular}

Pada tabel diatas diperoleh hasil konsentrasi larutan soda api yang optimal adalah187.5 M, dimana pada konsentrasi tersebut komposisi soda api lebih banyak yaitu 150 gr dan dilarutkan pada volume air $20 \mathrm{ml}$. Pada konsentrasi tersebut larutan soda api lebih kental dan pekat, sehingga dapat mengelupas cat dengan cepat yaitu dengan waktu 10 menit.

\section{KESIMPULAN}

Kriteria dan sub-kriteria yang digunakan untuk menentukan alternatif cairan pebersih cat antara lain: Kriteria pertama Ekonomi dengan sub-kriteria Harga murah dan Konsistensi harga, Kriteria kedua Lingkungan dengan sub-kriteria pencemaran rendah, dan ramah lingkungan, Kriteria ketiga Teknis dengan sub-kriteria Ketersediaan bahan banyak dan Kemudahan mendapatkan bahan, Kriteria keempat Konsentrasi dengan sub-kriteria cairan sedikit dapat merontokkan banyak cat dan luasan media yang dibersihkan, dan kelima Jurusan Teknik Industri Fakultas Teknik Industri UPN “Veteran" Yogyakarta adalah Kriteria Konsentrasi dengan sub-kriteria proses pengelupasan cat lebih cepat dan mengurangi waktu tunggu.

Pengambilan keputusan memilih alternatif cairan pembersih cat pengganti thinner menggunakan metode ANP software Super Decisions menghasilkan nilai prioritas soda api lebih tinggi yaitu 0.67617 atau $67.6 \%$ dibandingkan dengan nilai prioritas thinner yaitu sebesar 0.392383 atau $39.3 \%$. Jadi soda api merupakan sebagai alternatif cairan untuk mengganti thinner sebagai cairan pembersih cat.

Konsentrasi cairan soda api $(\mathrm{NaOH})$ yang optimal adalah $187.5 \mathrm{M}$ dengan campuran massa 150 gram dengan volume air/aquades sebesar $20 \mathrm{ml}$ menghasilkan waktu pengelupasan cat selama 10 menit.

\section{DAFTAR PUSTAKA}

1. [1] Antony Jiju, (1998). "Some key things industrial engineering should know about experimental design". Logistic Information Management. Vol. 11.

2. [2] Arif Genta, (2015) Sistem Pendukung Keputusan Pemilihan Telepon Seluler Menggunakan Analytic Network Process (ANP). Jurnal Teknik Informatika Universitas Dian Nuswantoro Semarang

3. [3] Desvia Safitri, Mochammad Chaerul, Emenda Sembiring, (2015). Multi Kriteria Terhadap Pemilihan Alternatif Pengelolaan Sampah Organik Dengan Menggunakan Metode Analytic Network Process (ANP). Jurnal Teknik Sipil dan Lingkungan Institut Teknologi Bandung

4. [4] Kuncahyo, Priyohadi, dkk (2013). Analisa Prediksi Potensi Bahan Baku Biodesel sebagai Suplemen Bahan Bakar Motor Diesel di Indonesia. Jurnal Teknik Pomits Vol.2, No.1, ISSN : 23373539. Jurusan Teknik Perkapalan, Fakultas Teknologi Kelautan. Institut 
Teknologi Sepuluh November.

5. [5] Saaty, T. L. (2008). The

Analytycal etwork Process. Ellsworth Avenue : Pittsburgh.

6. [6] Tanjung. H, dan Devi. A. (2013), Metodologi Penelitian Ekonomi Islam, Gramatika Publising : Bekasi 